\title{
MASTER BOPY
}

\section{DESCRIPTION OF PUREX PLANT PROCESS}

By

E. R. Irish

May 19, 1959

[Date Declassified]

Hanford Atomic Products Operation

General Electric Company

Richland, Washington

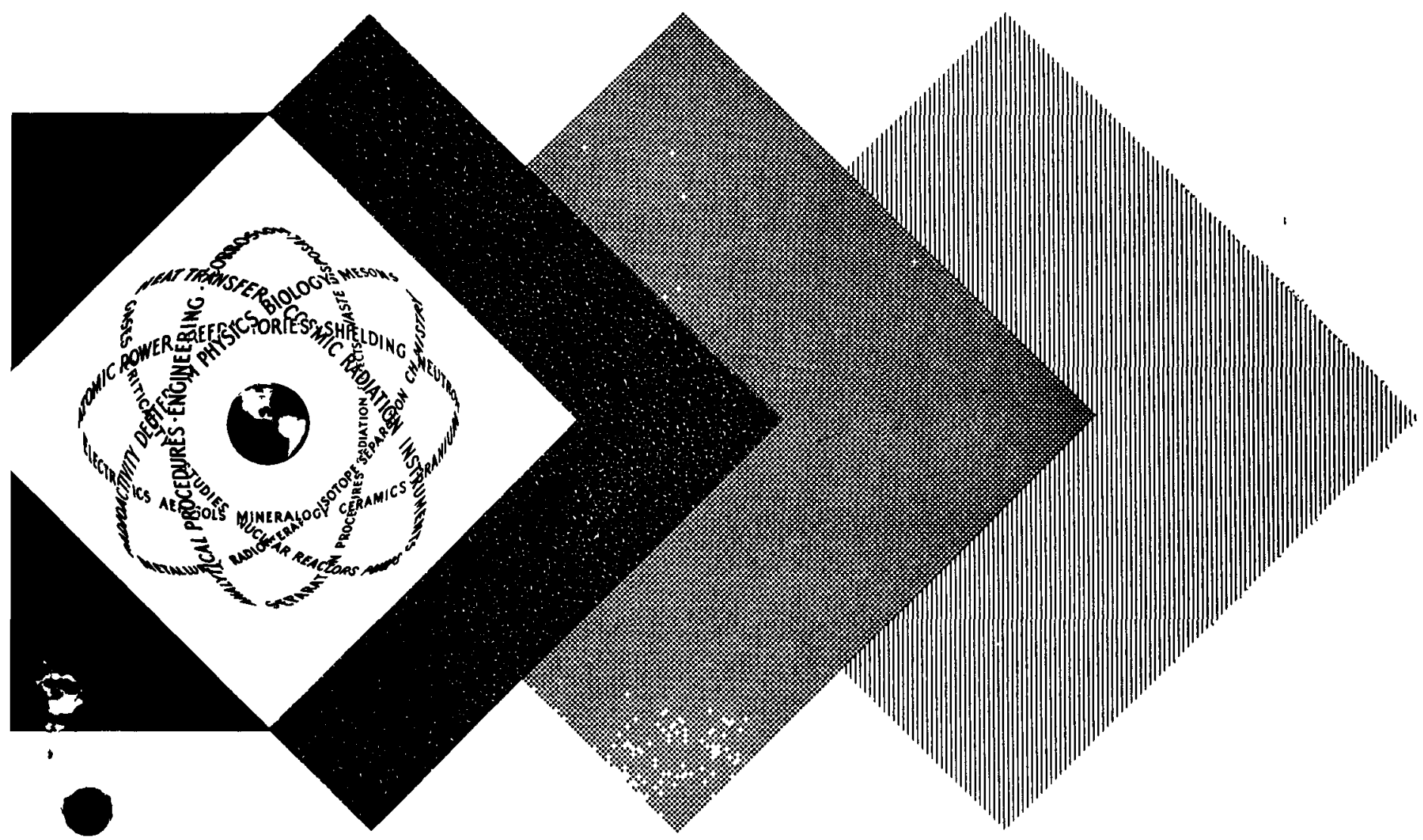

UNITED STATES ATOMIC ENERGY COMMISSION

Technical Information Service 
Work performed under Contract W-31-109-Eng-52.

\section{LEGAL NOTICE}

This report was prepared as an account of Government sponsored work. Neither the United States, nor the Commission, nor any person acting on behalf of the Commiantion:

A. Makes any warranty or representation, expressed or Implled, with reopect to the sccuracy, completeness, or uaefulness of the information contained in this report, or that the use of any Information, apparatus, method, or process disclosed in this report may not infringe privately owned rights; or

B. Assumes any liabilities with respect to the use of, or for damages resulting from the use of any information, apparatus, method, or procese disclosed in this report.

As used in the above, "person acting on behnlf of the Commisalon" includes any employee or contractor of the Commiasion, or employee of such contractor, to the extent that such employee or contractor of the Commisaion, or employee of auch contractor prepares, disseminates, or provides access to, any information pursuant to his employment or contract with the Commiseion, or his employment with such contractor.

This report has been reproduced directly from the best available copy.

Printed in USA. Price \$0.50. Available from the Office of Technical Services, Department of Commerce, Washington 25, D. C.

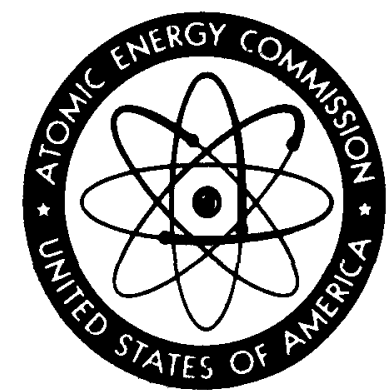




\section{DISCLAIMER}

This report was prepared as an account of work sponsored by an agency of the United States Government. Neither the United States Government nor any agency Thereof, nor any of their employees, makes any warranty, express or implied, or assumes any legal liability or responsibility for the accuracy, completeness, or usefulness of any information, apparatus, product, or process disclosed, or represents that its use would not infringe privately owned rights. Reference herein to any specific commercial product, process, or service by trade name, trademark, manufacturer, or otherwise does not necessarily constitute or imply its endorsement, recommendation, or favoring by the United States Government or any agency thereof. The views and opinions of authors expressed herein do not necessarily state or reflect those of the United States Government or any agency thereof. 


\section{DISCLAIMER}

Portions of this document may be illegible in electronic image products. Images are produced from the best available original document. 
DESCRIPTION OF PORRXX PIANTI PROCASS

\section{INIRODUCTION}

The Purex process is a continuous solvent extraction process for irradiated uranium for the separation and decontamination of plutonium and uranium from each other and from flssion products. Much information has been documented $(2,11)$ in the unclassified literature in regard to the process bases, chemistry, and possible flowsheets based on laboratory and pilot plant work. However, since the Purex Plant has been in production operation at the Hanford Atomic Products Operation since 1956, many revisions have been made to the process flowscheme and details. These process improvements have been the result of coordinated in-plant and laboratory develupment programs. The purpose of this document is to present a brief summary, with reference literature for details, of pertinent and important process flowsheet conditions $(12,19)$ which are in use in the Purex Plant.

\section{OVER-ALI PROCESS DESCRIPTION}

The Purex Plant process can be divided into seven major steps or unit operations:

1. irradiated uranium dissolution (including jacket removal) and feed preparation;

2. gross decontamination and recovery of uranium and plutonium from fission products;

3. partitioning of the uranium and plutonium;

4. final decontamination and recovery of plutonium (including anion exchange tail-end treatment);

5. final decontamination and recovery of uranium;

6. solvent recovery; and

7. nitric acid recovery (including waste concentration and disposal).

In addition, several auxiliary steps are required for the coordinated operation of the plant.

Initially, the solvent extraction portion of the plant consisted of: a) a codecontamination cycle for gross decontamination of plutonium and uranium from fission products; b) a partition cycle for further decontamination from flssion products and separation of plutonium and uranium from each other; and c) final decontamination cycles for both plutonium and uranium. Final products were concentrated by boil-down to concentrated nitrate solutions 
for further processing. Wastes from each cycle were concentrated; nitric acid was recovered by distillation for re-use in the process, and the wastes were neutralized and stored. Used solvent was chemically washed and recycled to the process.

As discussed in Reference 11, the above flowscheme is only one of several possible arrangements of the Purex process. A major improvement in the processing scheme has been incorporated in the Purex Plant by conversion from a three-cycle to a two-cycle solvent extraction flowsheet employing the backcycling of waste (2). Figures 1,2 , and 3 show the details of the over-all process flowsheet, and Table I summarizes the design criteria for the solvent extraction columns $(6,12)$. Over-all process performance with these flowsheets and process equipment has been demonstrated on a plant scale as follows:

$$
\begin{array}{cc}
\text { Separation of U from Pu } & >10^{7} \\
\text { Separation of Pu from U } & 10^{6} \\
\text { Decontamination of F.Ps from Pu } & >10^{8} \\
\text { First Cycle DF } & =2 \times 10^{4} \\
\text { Second Cycle DF } & =2 \times 10^{2} \\
\text { Anion Exchange DF } & \Rightarrow 3 \\
\text { Fecontamination of F.Ps from U } & 10^{7} \\
\text { First Cycle DF } & =2 \times 10^{4} \\
\text { Second Cycle DF } & 5 \times 10^{2} \\
\text { Plutonium \& Uranium Recovery } & 99.9 \% \\
\text { Acid Recovery - Dissolving } & 70 \% \\
- \text { Solvent Extraction } & 95 \% \\
\text { Solvent Recovery } & 99.7 \%
\end{array}
$$

The major items contributing to the successful transition from the three-cycle to the two-cycle flowsheet include:

1. improved pulse column technology;

2. improved solvent treatment methods;

3. new technology for anion exchange purification of plutonium; and

4. increased process "know-how".

In the following sections each of the major unit operations will be described briefly in conjunction with reference to appropriate flowsheet Figures 1, 2 , and 3. Notes on these figures define the flow bases, temperatures and other process conditions. 

Following centrifugation, the solution is adjusted to the proper uranium and acid concentration for solvent extraction. Normally, no plutonium valence adjustment with sodium nitrite is necessary because of the presence of adequate nitrite ion lesulting from radiolysis of nitrate ion in the dissolver solution.

B. Gross Decontamination from Fission Products

With reference to Figures 1 and 2 , and solvent extraction process descriptions elsewhere $(2,11)$, stepwise descriptions of the solvent extraction flowsheets are unnecessary. However, major facets will be mentioned. In regard to the HA-HS Columns, essentially the HS Column is an extension of the HA Column scrub section, but being separate, it may be operated at $70^{\circ} \mathrm{C}$ with the $\mathrm{HA}$ Column operated at $35^{\circ} \mathrm{C}$ for maximum decontamination as discussed in Reference 2. This procedure has not been adopted in the Purex Plant, however, because all solvent solutions are maintained below $55^{\circ} \mathrm{C}$ for safety reasons with existing equipment and solvent.

The HAO stream is a solvent stream consisting of backcycled IBSU (returning fission products removed in the IBS Column) and HOO recycled solvent used to minimize uranium reflux in the HA and HS Columns. Sodium nitrite may be added to oxidize any entrained ferrous ion from the IBS Column, but this is not usually necessary.

The $3 W B$ stream, as shown in Figure 3 , is a concentrated solution of second cycle wastes being backcycled (2) for recovery of plutonium and uranium losses from these cycles. These waste acid solutions are steam-stripped through six bubble-cap trays for removal of entrained solvent prior to concentration. Most of the nitric acid entering the HA Column enters via this solution.

Both the HA and HS Columns have special cartridges defined in Table I and are operated with the solvent phase continuous. Thus, the aqueous-organic interfaces are located at the bottom ends of the columns; highly radioactive solids which accumulate on these interfaces are entrained with the aqueous phases leaving the columns and thus do not follow the productbearing solvent phases leaving the columns. The combination of the special cartridges and the bottom-interface locations resulted in a 5-to 10-fold improvement in fission product decontamination compared with top-interface locations.

Operation of the columns with bottom interfaces was dependent on two major developments. Satisfactory plastic plates with adequate radiation stability (integrated exposure greater than $2 \times 10^{9} \mathrm{R}$ ) were made from linear polyethylene. Satisfactory interface control (under pulsed column and slightly emulsified conditions) was achieved by use of a float-type interface detector (7) for remote locations. 
C. Partitioning of Plutonium and Uranium

Two columns, IBX and IBS, are utilized for pertitioning of plutonium and uranium. Use of two short columns rather than one long column permits easier installation of the columns in canyon cells. Also, such a flowscheme permits the IBSU backcycle which provides additional fission product decontamination for both uranium and plutonium.

D. Final Plutonium Decontamination

As shown in Figure 2, the plutonium is further decontaminated from fission products by solvent extraction in the $2 A$ and $2 B$ Columns and from both fission products and uranium by an anion exchange purification step (16). The $2 A$ Column is operated with the solvent phase continuous.

All equipment downstream of the partitioning step is designed to be geometrically safe for plutonium solutions. This feature is important from the standpoint of preventing a criticality excursion when processing quite concentrated plutonium solutions. Two other concepts are used for critical mass control elsewhere in the plant: (a) batch-size control where feasible, and (b) safe solution concentration elsewhere. The primary critical mass control feature, however, is maintenance of chemical conditions (1) to prevent the precipitation and accumulation of a critical mess of plutonium. In the acidic Purex proress, the problem exists primarily only where plutonium concentrations become high.

Solvent for the Final Plutonium Cycle is shown to be from the No. 2 Solvent System, the low-activity solvent used also in the Final Uranium Cycle, for maximum fission product decontamination. If the No. I Solvent System, the high-activity solvent used in the First Cycle, provides adequate decontamination of the solvent from fission products, $2 A X$ can be supplied from this system; such has proved to be possible in the plant when the alkalinepermanganate solvent washing process (described later) is used. In this way the $2 B W$ can be backcycled to IBXF, but caution must be used to prevent routing of excessive nitrite ion (very extractable) to the IBXF and oxidizing the IBX Column solutions.

The anion exchange process is performed in Higgins $(9,10)$ continuous anion exchange columns using Permutit SK resin (20 - 40 mesh). A $0.045 \mathrm{M} \mathrm{H}_{2} \mathrm{SO}_{4}$ solution is used in $2 B X$ in order to complex Pu IV to permit a low $2 B P$ flow; thus, the XAF flow rate is maintained at a minimum to maximize the hold-up time in the XA Column for anion resin adsorption, kinetics of adsorption being the controlling factor. Following elution of the plutonium from the $\mathrm{XC}$ Column, the solution is concentrated in a titanium concentrator to minimize introduction of impurities from corrosion; tantalum would also be suitable for this purpose.

E. Final Uranium Decontamination

As shown in Figure 2, the ICU stream is first steam stripped (through six bubble-cap trays) for removal of entrained solvent and then concentrated. 


\section{HW -60116}

(Steam pressure is limited to a maximum of $30 \mathrm{psig}$ for safety reasons.) Ferrous sulfamate is added to the 2 IF to reduce trace amounts of plutonium so that the plutonium will not be extracted in the $2 D$ column. The $2 D$ Column is operated with a high degree of saturation, resulting in approximately five percent of the uranium in the 2D Column feed being backcycled to $3 \mathrm{WB}$, in order to maximize fission product decontamination. The 2EU is concentrated in equipment identical to that used for ICU and $3 W B$ and transferred to a storage tank for further processing by calcination to the oxile.

The 2D Column is operated with the solvent phase continuous and a bottom interface similar to the HA Column. A twenty-fold increase in fission product decontamination was effected by the conversion of this column from aqueous to solvent phase continuous even though the "solvent extraction" decontamination factor should not have been different. This significant improvement iesulted because decontamination in this column is limited by particulate rather than soluble fission products (primarily $\mathrm{Zr}-\mathrm{Nb}$ ).

The plastic plates in the 2D Column are fluorothene because they were installed a year before the new linear polyethylene plates used in the HA Column. The fluorothene plates have adequate radiation resistance $\left(10^{\circ} \mathrm{R}\right)$ for use in this low-activity field.

\section{F. Solvent Recovery}

Two solvent systems, low-activity (No. 2) and high-activity (No. 1) systems, are used in the Purex Plant. The low-activity system simply employs a dilute sodium carbonate wash of the solvent in the 20 Column, followed by centrifugation or decanting for removal of solids and aqueous solution. Such a procedure normally maintains solvent of adequate quality. Since approximately 0.3 percent of the solvent processed in the plant is lost by chemical reaction, entrainment, and volatilization, fresh solvent is occasionaliy added to the No. 2 system, and solvent from the No. 2 system is then added to the No. 1 system for make-up solvent.

With the much more severe conditions of exposure of the No. 1 system solvent, a more comprehensive washing procedure is used as shown in Figure 3. The washing consists of good contacting of the solvent with an alkaline-permanganate solution first, where the permanganate is reduced to manganese dioxide, a good scavenger for diluent degradation products and particulates. The solvent is next washed with dilute acid for removal of residual manganese dioxide and finally washed with dilute sodium carbonate alone.

The contactors for all three operations in the plant are different because of the presence of original equipment in the plant. However, all three contacts could be made in identical equipment achieving adequate contacting and separation of 15 to 30 minutes. No centrifugation is required with the above process. 
Chemical solutions used for solvent washing are combined with the neutral1zed IWW from solvent extraction processing, concentrated, and stored in large underground mild-steel tanks. Infrequently, gross amounts of solvent nave been discarded to separate storage areas because of contamination with grease or paint resulting from leaks out of process equipment. No solvent which has remained in routine process use has required discarding.

\section{G. N1tric Ac1d Recovery añd Waste D1sposal}

As shown in Figure 3 , the only acid waste from solvent extration is HAW. Nitric acid is recovered from this waste by a double-distillation, absorption, and fractionation according to the flowsheet specified. No steamstripping of this acid is performed; the entrained solvent is decanted and returned to process, and the dissolved solvent is distilled or hydrolyzed. The acid product recovered from these operations has been decontaminated from fission products by a factor of $1 \times 10^{6}$ and is re-used in the process wherever possible without introducing excessive rission products. No problem of ruthentum volatilization has resulted from the acid recovery process.

The IWW waste solution containing essentially all of the fission products is neutrallzed with sodium hydroxide and stored in large, underground mildsteel (SAE-1020) tanks under boiling conditions as described in Reference 15. The concentration of these wastes must be maintained below $8 \mathrm{M}$ sodium ion to prevent precipitation of sodium salts. The precipitates (iron salts primarlly) in the tank scavenge most of the $\mathrm{Zr}-\mathrm{Nb}$, Ce, and $\mathrm{Sr}$ fission products leaving $\mathrm{Cs}$ and $\mathrm{Ru}$ in the supernate. Because of this tendency for concentration of the high heat-generating $\mathrm{Zr}-\mathrm{Mb}$ and $\mathrm{Ce}$ fission products in the solids, large air-lift recirculation tubes are used to turn the solution in the tanks over at rates of several tholisand gallons per minute to alleviate a tendency for localized over-heating, which would result in uneven boiling. The vapors from the tank are condensed, and most of the condensate is returned to the tank. The remainder of ths condensate is returned to the plant and used for acid distillation water prior to disposal to the ground via caverns (15).

Use of the formaldehyde process in the Purex Plant is contemplated for denitration of nitric acid in IWW $(5,14)$. This process has many economic advantages in addition to its maln justification of reducing the solids content (six-fold) and volume (three-fold) of high-level wastes for ultimate storage.

\section{SPECIAL FEATURES}

\section{A. Process Control}

Many of the process control techniques and devices used in the plant are standard for chemical plants. However, special equipment is used for 
sampling the radiogctive solutions, and special handling is required for analyses. Several in-line analytical instruments (18) are used for continuous measurement of $\mathrm{pH}$, plutonium and uranium concentrations, and gamma activities of solutions. These instruments provide much assistance for detecting off-standard conditions at an early time in their development and for 9 lding in the understanding of the process during normal and test operotions.

Continuous flow streams are generated either by pumps (4) or gravity-flow, and flow measurement and control (4) are achieved by remotely-operated rotameters and diaphragm-operated valves, respectively.

The evaluation of the allowable departures from flowsheet and the sensitiveness of process variables is largely dependent upon which type of flowsheet is being evaluated. For example, a flowsheet employing extensive waste backcycle can be extremely insensitive to deviations from flowsheet as compared to a process involving no backcycle. Sensitiveness of process variables is also dependent upon specific details, such as: 1) interface position, 2) cartrudge design, 3) critical mass considerations, 4) product specifjcations, 5) how close the plant is being pushed to capacity, 6) frequency of analytical checks for off-standard conditions, 7) degree of technical process supervision, 8 ) the existence of secondary indications of off-standard conditions, and 9 ) rate of process response or turnover.

In general, instrumentation and analytical techniques should be capable of two percent precision. An equally nigh degree of accuracy is not generally recessary, except in isolated cases such as nuclear materials accountability. Operating and process control personnel rapidly develop a "feel" ior the various biases in the data.

HAPO experience has shown that \pm 5 percent variation in composition or flow rate of most streams can be tolerated. However, certain key streams should ve controlled more closely. For example, in the uranium extraction columns, close control of solvent uranium saturation is required to optimize decontamination without incurring excessive plutonium losses. Temperatures should be controlled with $\theta$ precision of $\pm 2^{\circ} \mathrm{C}$ as wider fluctuations can result in column upsets due to changes in phase behavior.

A thorough evaluation of allowable flowsheet departures cannot be made sufficiently geners l to be realistic, and such an evaluation should be made specifically for the proposed flowsheet with consideration given to the points outlined above.

\section{B. Waste Rework}

Off-standard aqueous streams are reworked occasionally to recover uranium or plutonium. Such streams usually consist of concentrated acid wastes, solvent recovery wastes, cell drainage, flushes and spill solutions. The procedure for handling all aqueous streams is generally the same. The 
rework stream is acidified, if necessary, to $4-7 \mathrm{M}$ nitric acid and then bolled or refluxed until all TBP and its degradation products are hydrolyzed to phosphoric acli and the diluent boiled off. The time required to destroy TBP depends on temperature, the concentration of nitric acid, salts present, and on the IBP concentration. Unfortunately, due to difficulties involved in measuring TBP concentrations in waste streams, no fixed formula for reflux time has been obtained. Rather, a trial method is used to determine completion of the hydrolysis. A small portion of the rework solution is blended into the First Cycle feed at volume ratios of about 1 to 20 , and the recovery efficiency, decontamination performance, and stability of the first extraction column is observed. If the batch is processed satisfactorily, the remainder of the rework is blended off in the same manner. However, if the trial is not successful, the rework solution is refluxed for a longer period. To date, concentrated acid wastes which contain a minimum of entrained TBP and which have boiled more than 50 hours have been processed successfully by blending into the feed for First. Cycle feed make-up solution. Other aqueous rework solutions mentioned above have required 12 to 22 days of refluxing before they could be processed. In refluxing rework material, as in concentrating any Purex solution, care must be taken not to exceed $135^{\circ} \mathrm{C}$ (the de-nitration temperature of "Red Oil").

Recently processes have been developed to rework aqueous waste solutions, particularly concentrated acid waste, through anion exchange resins for the recovery of plutonium. Several problems remain to be resolved in this process, one of which is solids removal. The composition of concentrated acid waste is being studied, and the ion exchange method of recovery appears promising. One item of interest learned from plant experience is that a solid iron salt of dibutylphosphate is formed in concentrated acid wastes which has a tendency to coagulate and plug lines. This salt is slurryable in dilute (5 weight percent) sodium hydroxide.

The processing of off-standard organic solution, notably large volumes of spilled organic which have dissolved paint and grease from cell floors, has not been always successful. Amercoat paint used at Hanford acts as an emulsifying agent and upsets the extraction columns so that blending is not possible. If the organic contains recoverable product and the volume is such that it cannot be conveniently distilled and hydrolyzed, then batch contacting is used. Usually carbonate or caustic solutions will adequately strip the product from the solvent so that the stripped solvent can be discarded. The stripped solution is then treated as offstandard aqueous rework solution.

\section{RGHFRENCES}

1. Brunstad, A., "Polymerizetion and Precipitation of Plutonium IV in Nitric Acid", HW-54203 (Unclassified), December 17, 1957.

2. Cooper, V.R., and M. T. Walling, Jr., "Aqueous Processes for Separation and Decontamination of Irradiated Fuels", Proceedings of the Second International Conference on the Peaceful Uses of Atomic Energy, United Nations, Paper 2409 (1958). 
HW -60116

3. Courtney, J. J., and B. E. Clark, Jr., "An Introduction to the Purex Plant", HW-32413 (Secret), Jully 15, 1954.

4. Dunn, J., and H.M Jones, "Flow Generation, Measurement, and Control", Symoosium on the Reprocessing of Irradiated Fuels, Brussels, Belgium, TID-7534, Book 3, pp. 869 - 891, (1957).

5. Evans; T. F., "The P1lot Plant Denitration of Purex IWW with Formaldehyde", HW-58587, (Unclassified), February 23, 1959.

6. Geier, R. G., "Application of the Pulse Column to the Purex Process", Symposium on the Reprocessing of Irradiated Fuels, Brussels, Belgium, TID-7534, Book 1, Pp. 107 - 129,(1957).

7. Hahn, K. J., and H. M. Jones, "A Remotable Float-Type LIquid Interface Controller", HW-55166 (Unclassified), February 27, 1958.

8. Harty, W. M., "The Design Philosophy of Remote Operation and Maintenance of Separations Facilities", Chemical Engineering Progress Symposium Series, No. 13, Volume 50, pp. 115-121, (1954).

9. Higgins, I. R., "Mechanical Features of the Higgins Continuous Ion Exchange Column", ORNL-1907 (Unclassified), September 29, 1955.

10. Higgins, I. R., "Countercurrent Liquid-Solid Mass Transfer Method and Apparatus", U.S. Patent No. 2,815,322, December 3, 1957.

11. Irish, E. R., and W. H. Reas, "The Purex Process - A Solvent Extraction Reprocessing Method for Irradiated Uranium", Symposium on the Reprocessing of Irradiated Fuels, Brussels, Belgium, TID-7534, Book 1, pp.83 106, (1957).

12. Irish, E. R., "Process Specifications for Operational Control - Purex Plant (Revision No. 1)", HW-56933 (Secret), November 17, 1958.

13. Irish, E. R., "Purex Plant Production Capability Derived from Unclassified Information - Pilot Evaluation of Final Uranium Cycle", HW-59837 (Secret), March 30, 1959.

14. Oberg, G. C., "Denitration of Purex Plant IWW", HW-60161 (Secret), May 1, 1959 .

15. Platt, A. M., "The Retention of High Level Radioactive Wastes", Symposium on the Reprocessing of Irradiated Fuels, Brussels, Belgium, TID-7534, Book 1, pp. $389-406$, (1957).

16. Ryan, J. I., and E. J. Wheelwri "The Recovery, Purification, and Concentration of Plutonium by Anion Exchange in Nitric Acid", HW-55893 (Confidential), January 2, 1959. 
11

17. Schmidt, W. C., "Treatment of Geseous Effluents", Symposium on the Reprocessing of Irradiated Fuels, Brussels, Belgium, TID-7534, Book 1, pp. $362-377$, (1957).

18. "Operation and Maintenance Manual for In-I.ine Analytical Instruments", HW-41093 (Unclassified), February 1, 1956.

19. "Purex Technical Manual", HW-31000 (Secret), March 25, 1955. 
TABLE 1

SOLVENT EXTRACTION COLUMN DATA

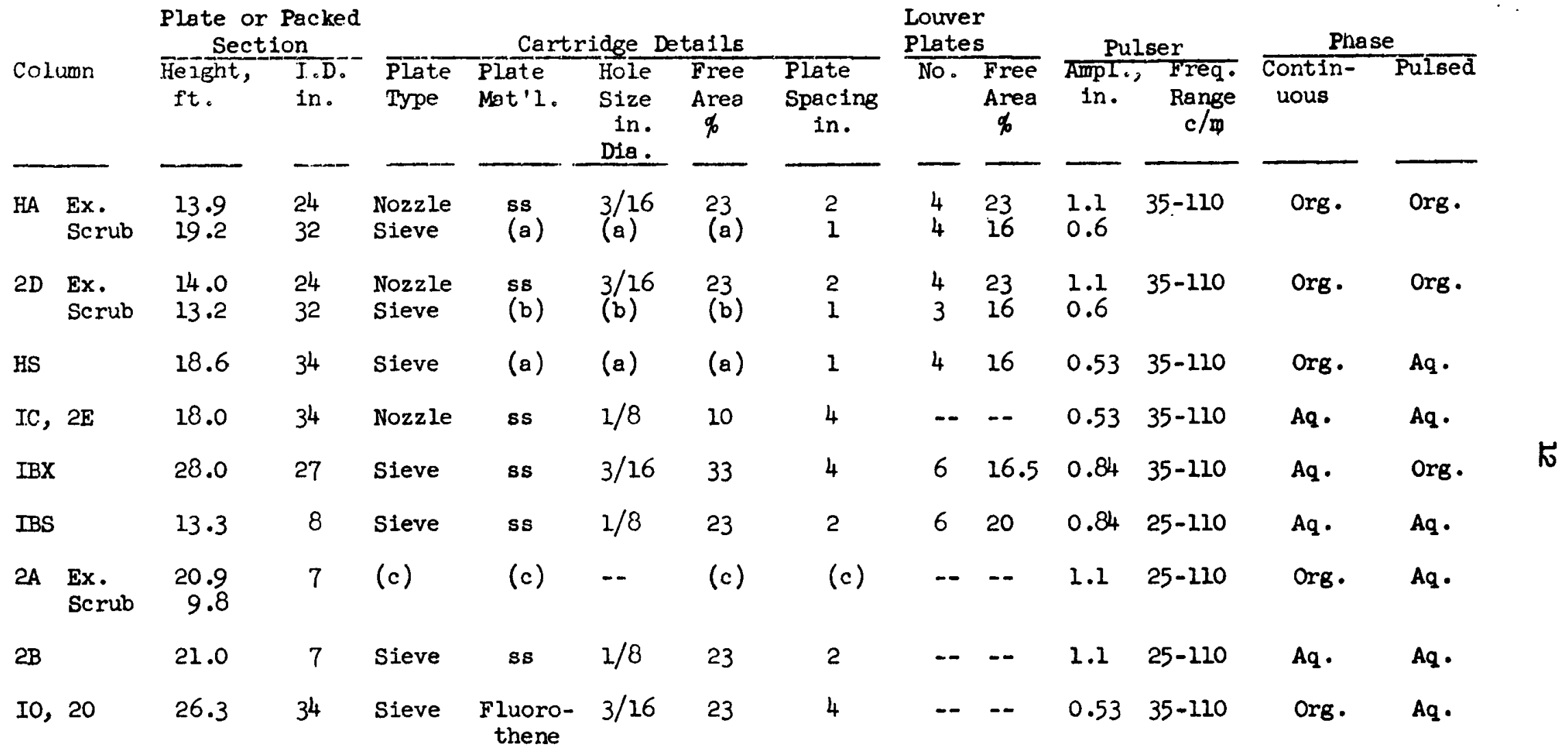

(a) Cartridge composed of $21 \%$ free area stainless steel (ss) plates and 23\% free area linear polyethylene plates, grouped alternately four stainless steel plates and two polyethylene plates. Hole diameters in stainless steel plates $=0.085 \mathrm{in} . ;$ polyethylene plates $=0.1875 \mathrm{in}$.

(b) Cartridge composed of alternate pairs $21 \%$ free area stainless steel plates and 23\% fluorothene plates. Hole diameters in stainless steel plates $=0.085 \mathrm{in.}$; fluorothene plates $=0.1875 \mathrm{in}$.

(c) Packed with 1 in. fluorothene Raschig rings. 


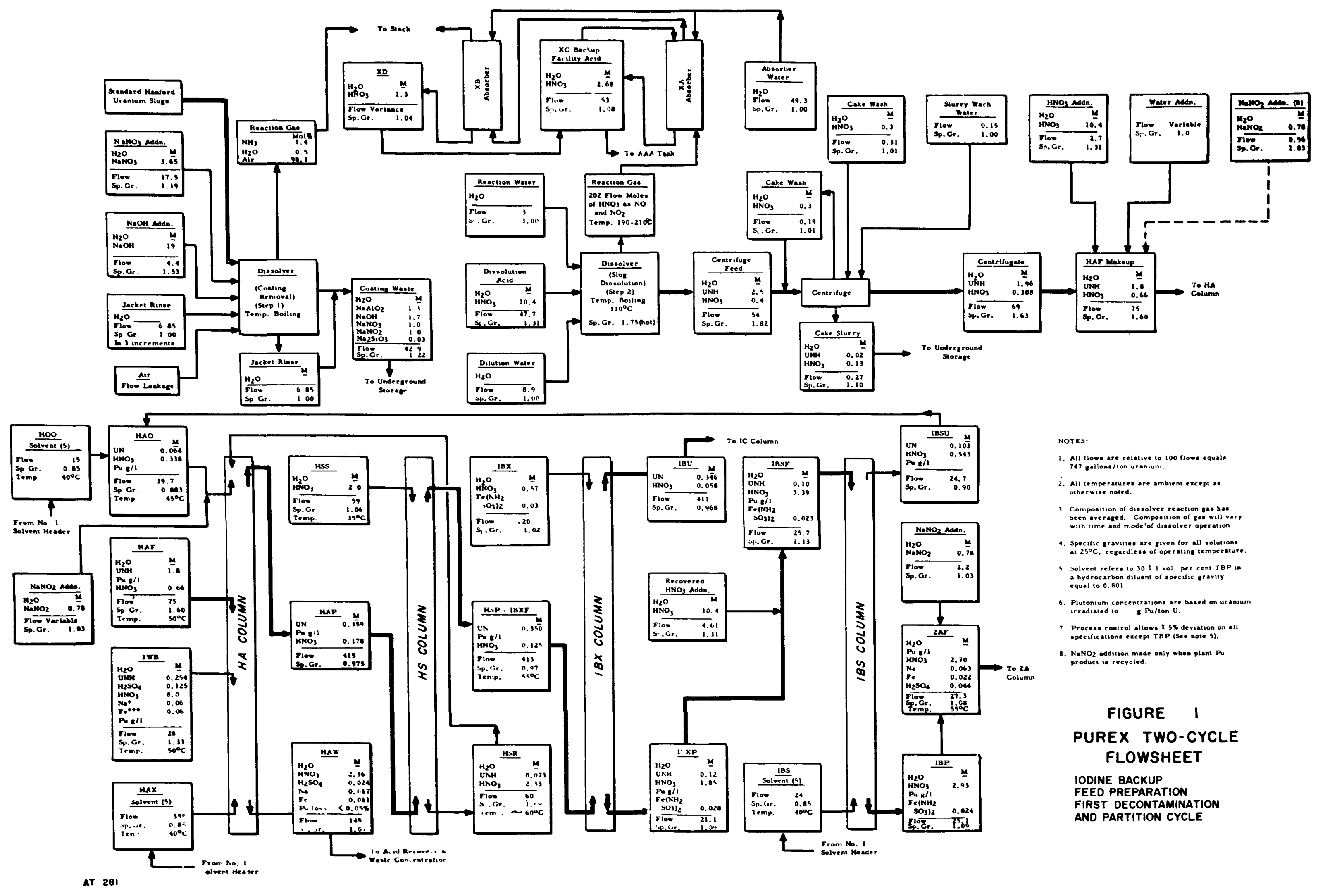



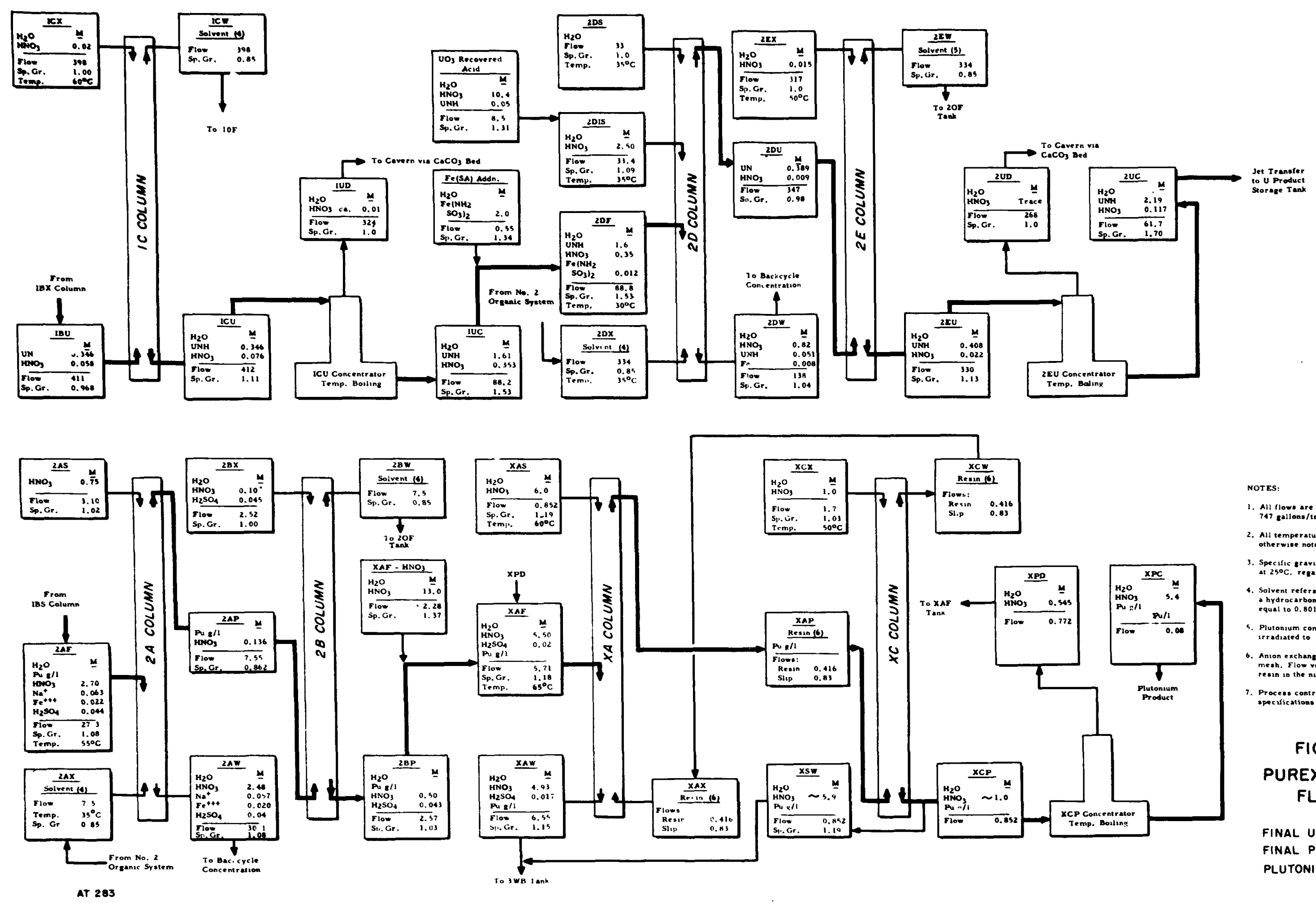

votes.

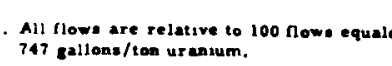

2. All temperatures are embient except a.

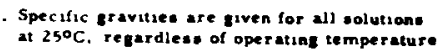

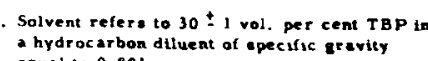

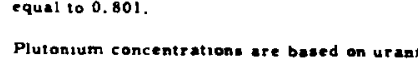

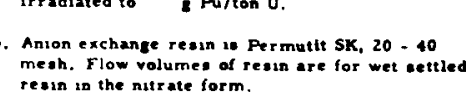

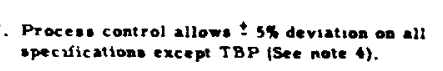

FIGURE 2

PUREX TWO-CYCLE FLOWSHEET

FINAL URANIUM CYCLE PLUTONIUM ION EXCHANGE 


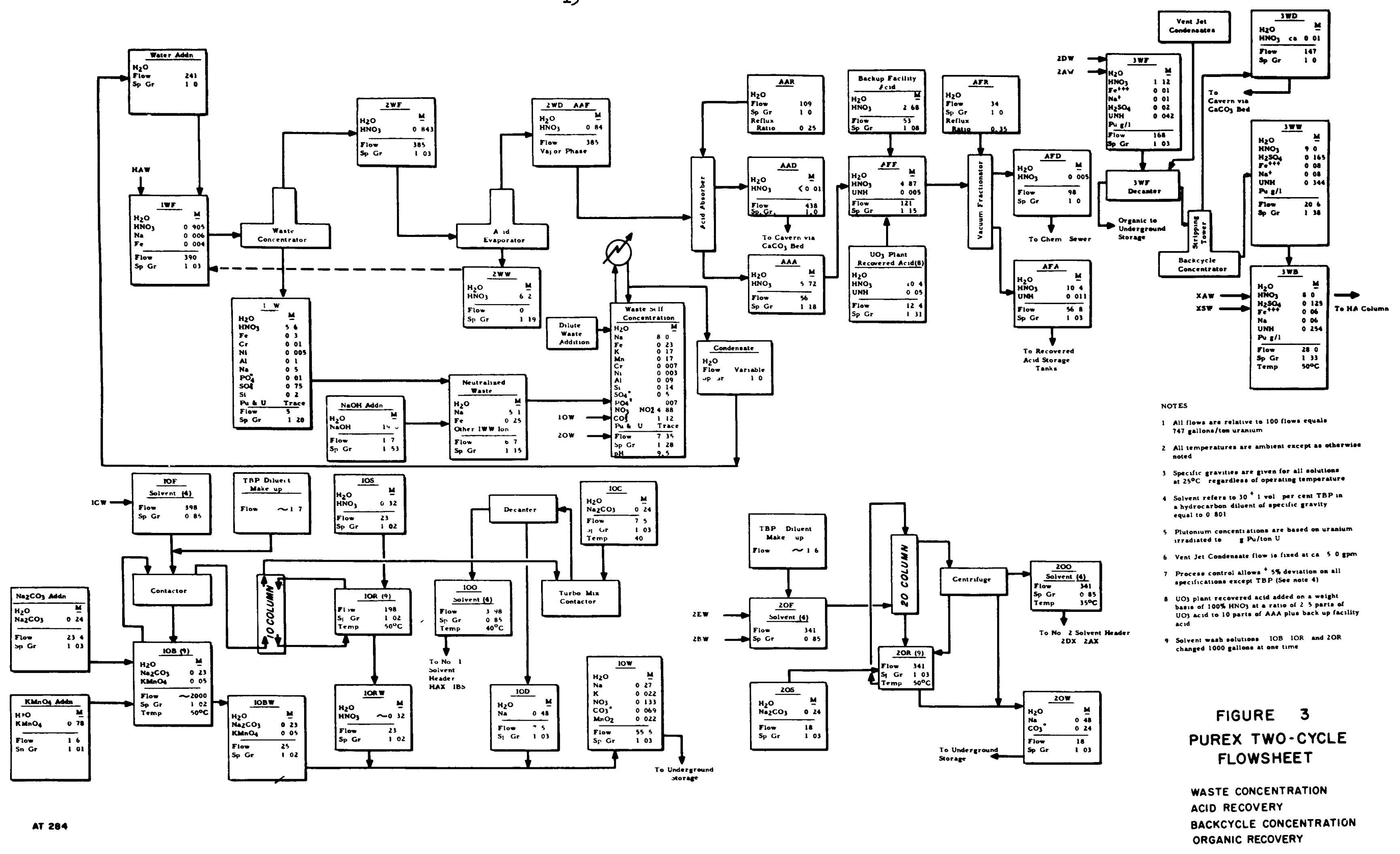

